\title{
Management of Student Personnel Services in Nigerian Universities through the Application of Information and Communication Technology
}

\author{
Ugomma Ebirim, ${ }^{\mathrm{x}}$ Ochai, Godwin O. and Obasi S. N. \\ Department of Adult Education, University of Nigeria
}

\begin{abstract}
This study investigated the application of Information and communications technology (ICT) in the management of student personnel services in north central Nigeria. The study was a descriptive survey. The population of the study comprised 1,294 respondents made up of 763 personnel in federal and 531 personnel in state universities. Out of the population, samples of 448 respondents made up of 281 personnel in federal and 167 personnel in state universities were selected by random sampling technique. The instrument used for data collection was a 28-item questionnaire. Data collected were analyzed using mean, standard deviation and t-test. The findings of the study showed that ICT knowledge can be applied in the areas of accessing results on line, filing of student personal data and communication. It was also revealed that application of ICT can be improved through the training of students and personnel in the use of ICT, provision of ICT facilities and funding of ICT projects in university. It was recommended that the state government should supply the necessary ICT equipment to all adult literacy centers in the state. The state government should also improve the training of adult educators, personnel and learners in the use of ICT through seminar, workshop conference.

Key words: personnel management and applications of ICT in Africa Universities.
\end{abstract}

\section{Introduction}

The educational system in Nigeria has been delineated into different levels mainly pre-primary, primary, secondary and tertiary institutions. The increasing development of educational system at all levels brings greater demands on educational administrators and personnel services.

Student personnel services are aimed at the satisfaction of learners needs in the areas of provision of administration, registration, orientation, hostel accommodation health services, results, and supervision of school programmes. Apart from the normal classroom instruction, this facilitates the attainment of the desired educational objectives. In the view of Alani et al (2010) that provision of welfare services in all universities was inadequate and seemed to be responsible for learners' low level of satisfaction and poor motivation to learning. This may be partly as a result of the use of obsolete equipment in data collection, processing, storage and retrieval. The consequences of this may include examination malpractices, cultism, delay and sharp practices in allocation of hostel accommodation, computation of student results, inadequate communication between students and staff.

Becta (2008) defined Information and communications technology (ICT) as technology that is used to process, store, transmit, communicate, create or exchange information. In order words, ICT is the computing and communication facilities in education. In the context of this paper, ICT refers to technical systems that receive, process and store data. It facilitates student data management. With developments in information technology in the past decades, it is expected that ICT will be used for student personnel services to meet the challenges of modern day university management. Application of ICT in student personnel services will enhance administrative work, reduce occupational stress and improve student academic performance. It emphasized that the prominent role of ICT could be seen in advancing knowledge and skills necessary for effective functioning in the modern world. There is therefore the need to integrate ICT in student personnel services in universities in north central Nigeria for effective management.

According to Terry (2012), management is a distinct process consisting of planning, organizing, actuating and controlling, performed to determine and accomplish stated objective by the use of human beings and other resources. According to Lundy (1957), management is principally the task of planning, coordinating, motivating and controlling the efforts of others towards a specific objective. In the words of Koontz and O'Donnel (1974), management is defined as the creation and maintenance of an internal environment in an enterprise where individuals working together in groups can perform efficiently and effectively towards the attainment of group goals. In order words, management is a social interaction process involving sequence of coordinated events such as planning, organizing, controlling, supervision, budgeting and evaluation in order to use available human and marital resources to achieve a desired outcome in fast and most efficient ways in universities in the north central. 
North central is one of the geo-political zones among the six zones in Nigeria where there are several universities that share some peculiarity such as student personnel services and inconsistency in the application of ICT facilities in the management of universities. The fact that universities in North central are witnessing a tremendous growth in student enrolment has made the management of universities in north central complex thereby, creating challenges ranging from the management of student data, affective record keeping, computation of students results, course registration, supervision of students on campus and management of school finance, in agreement with these points, Adeyemi (2007) argued that there was no time in the history of education in Nigeria when schools and administrators have been faced with such multitudes of challenges than now. The administrators have been faced with such multitudes of challenges. The administrative functions in these universities are becoming increasingly complex in terms of enrolment, delay in computation of results, allocation of hostel accommodation etc.

The introduction of ICT in the managements of student personnel services could become an antidote in providing effective solutions to student personnel problems that would have been difficult, if not impossible to solve through human effort. Commenting on the areas of educational management where ICT can be implemented for efficient working of institutions, Ahmad (2011) opined that ICT can be used to maintain the personal record information of the students. ICT according to him can also be useful in maintaining the record of enrolment and attendance/leave information. Fees management and examination performance and analysis can be done efficiently through ICT.

There is no doubt therefore, that student personnel service has become more complex hence its management demands more from the administrators. The enormous rise in the number of students in the universities as well as the multiplicity of programmes have made university personnel to handle a very large quantity of data which must be accessed speedily to provide information for the university administration, National University Commission (NUC) and Ministry of Education for effective management and decision making process. Hence, the use of ICT in the management of student personnel services in universities becomes imperative.

It has however, been observed that in many universities in North central zone, ICT tools like computer, internet satellite and other telecommunication technologies that can aid teaching, learning and managerial functions are necessary for personnel management. It is against this background that the study sought to find out the application of ICT in the management of students personnel service in universities in the North central zone of Nigeria.

\section{Statement of Problem}

The tasks of meeting the needs of university students in developing countries Nigeria, inclusive are very demanding. Researchers, the government and the general public have expressed considerable concern on the need for the integration of ICT in the management of university system. This is because when ICT facilities are provided and utilized, would reduce occupational stress, which will result in greater administrative efficiency and academic productivity.

It has been observed however that ICT facilities seem not to have being applied in the management of student personnel services in universities in the north central zone of Nigeria. This may be as a result of inadequate provision of ICT facilities, constant power failure, computer illiteracy, inadequate training of students and personnel in the use of ICT. The problem of this study therefore is to find out how ICT can be applied in the management of student personnel services in universities in the north central zone of Nigeria.

\section{Purpose of the Study}

The purpose of the study is to find out the application of ICT in the management of student personnel service. Specifically, the study intent to:

1. Find out areas in which ICT can be applied in the management of student personnel service.

2. Ascertain procedures for the application of ICT in the management of student personnel service.

3. Determine likely problem that could hinder the application of ICT in the management of student personnel service.

\section{Research Question}

The following research questions guided the study.

1. In what areas can ICT be applied in the management of student personnel services?

2. What are the procedures for the application for ICT in the management of student personnel services?

3. What are the likely problems that could hinder the application of ICT in the management student personnel services?

\section{Hypotheses}

The null hypotheses were formulated at 0.05 degree of significance guided the study. 
HO1: There was no significant difference in the mean value of personnel in federal and personnel in state universities on areas in which ICT can be applied in the management of student personnel services.

HO2: There was no significant difference in the mean ratings of personnel in federal and personnel in state universities on likely problem that could hinder the application of ICT in the management of student personnel services.

\section{Design of the Study}

II. Methods

This research adopted a descriptive survey design. The study aimed at investigating the application of ICT in the management of student personnel service in universities in North central Nigeria.

\section{Area of the Study}

The zone is made up of five federal and six states universities approved by the National Universities Commission (NUC). These universities are in the north central zone of Nigeria and they have some peculiarities in terms of student personnel services and university administrative processes.

\section{Population of the Study}

The population of the study comprised 1,294 (federal 763, state 531) personnel in federal and state universities in the north central zone of Nigeria that are concerned with student personnel service. The categories of personnel used for the study include personnel in student affair department, personnel in the library department, personnel in bursary department and personnel in various faculties within the universities. The data were obtained to ensure that those used for the study were sufficiently knowledgeable about the variables under study and could supply useful information on the instrument (Academic Planning Unit of Universities 2009/2010)

\section{Sample and Sampling Techniques}

The sample of the study consists of 448 personnel and students were selected for the study. Applying stratified random sampling technique, four universities, (two federal and two states) were randomly selected from universities in north the central zone of Nigeria. Through simple random sampling technique, 281 personnel in student affairs, bursary department, library department and personnel in various faculties in federal and 167 personnel in state universities were selected from the four universities bringing the total sample to 448 personnel.

\section{Instrument}

The instrument for data collection was researcher-developed questionnaire titled "Application of ICT in the management of student personnel services questionnaire" (AICTMSPQ). A twenty-eight (28) item survey instrument was structured on a 4-point rating scale of Strongly Agree (SA), Agree (A) Disagree (D), and Strongly Disagree (SD) rated 4-1 points respectively. These items were developed from information obtained from literature reviewed and were based on the three research questions. These items elicited information from respondents on the application of ICT in the management of student personnel services in the universities in North central zone of Nigeria.

\section{Validation of Instrument}

The research instrument was face validated by three experts, two from Educational Administration and Planning and one expert from Measurement and Evaluation, Faculty of Education, University of Nigeria, Nsukka. The comments and criticisms made by these experts shaped the focus of the research in the final development of the questionnaire for the study.

\section{Reliability of Instrument}

The validated instrument was trial-tested to ascertain the reliability of the instrument using Cronbach alpha method. The reliability co-efficient was 0.71 . This indicated that the instrument was reliable.

\section{Method of Data Collection}

Three research assistants were trained and employed in the distribution of the questionnaire and collection of all the data. The data were collected after the respondents responded to the distributed research instruments. The entire instruments distributed were collected. This indicated one hundred percent retrieval of the research instrument. 


\section{Method of Data Analysis}

Data collected were analyzed using mean and standard deviation for the three research questions. The ttest statistic was used in answering the two null hypotheses formulated for the study. The level of significance was at 0/05. The two null hypotheses were accepted because the calculated value is less than the table value. Items of the research questions with mean score of 2.50 and above were regarded as accepted while any item with a mean score below 2.50 were rejected.

\section{Results}

The results are presented in tables 1-5 according to research questions and hypotheses that guided the study.

\section{Table 1: $\quad$ Mean Responses on Areas for the Application of ICT in the} Management of Students Personnel Service. S/N Areas for Application

1. Registration of students

2. Allocation of hostel accommodation

\begin{tabular}{cccccccc}
$\mathbf{X}$ & SD & Dec & \multicolumn{4}{c}{ SD } & \multicolumn{3}{c}{ Dec } & \\
& 2.98 & 1.09 & $\mathrm{~A}$ & 3.17 & 0.88 & $\mathrm{~A}$ \\
& 3.06 & 0.97 & $\mathrm{~A}$ & 3.21 & 0.97 & $\mathrm{~A}$ \\
& 3.27 & 0.89 & $\mathrm{~A}$ & 3.43 & 0.83 & $\mathrm{~A}$ \\
hers. & 3.05 & 0.98 & $\mathrm{~A}$ & 2.96 & 0.99 & $\mathrm{~A}$ \\
& 3.72 & 1.10 & $\mathrm{~A}$ & 3.26 & 0.94 & $\mathrm{~A}$ \\
sult. & 3.14 & 0.92 & $\mathrm{~A}$ & 3.28 & 0.82 & $\mathrm{~A}$ \\
& 3.43 & 0.70 & $\mathrm{~A}$ & 2.87 & 0.92 & $\mathrm{~A}$ \\
& 3.12 & 0.98 & $\mathrm{~A}$ & 3.05 & 1.13 & $\mathrm{~A}$ \\
3.36 & 0.80 & $\mathrm{~A}$ & 3.29 & 1.04 & $\mathrm{~A}$ & \\
3.23 & 0.84 & $\mathrm{~A}$ & 2.99 & 1.11 & $\mathrm{~A}$ & \\
3. & 3.43 & 0.74 & $\mathrm{~A}$ & 3.23 & 0.93 & $\mathrm{~A}$ \\
& 3.05 & 0.98 & $\mathrm{~A}$ & 3.31 & 1.03 & $\mathrm{~A}$
\end{tabular}

3. Accessing of result on-line.

4. Communication among student, teachers.

5. Use of ICT for creation activities.

6. The use of ICT for computation of result.

7. The use of ICT for records keeping

8. Orientation of new students.

9. Counseling services.

10. Filling of personal data

Use for faculty/developmental transfer.

12. Use of ICT for publication of results.

Table 1 presents the responses of personnel in federal and state universities on areas in which ICT can be applied in the management of student personnel services. A look at the table shows that items 1-2 are rated 2.98, $3.06,3.27,3.05,3.72,3.14,3.43,3.12,3.36,3.23,3.43$, and 3.05 for personnel in federal universities and 3.17, $3.21,3.43,2.96,3.26,3.23,2.87,3.05,3.29,2.99,3.23$, and 3.31for the states. This implies that both personnel in federal and state universities in North central zone agreed with Registration of students, allocation of hostel accommodation, accessing of result on-line and other items on the table as areas in which ICT can be applied in the management of student personnel services.

\section{Table 2: $\quad$ Mean Responses on Procedures for the Application of ICT}

S/N Areas for Application

Federal University State University

$X \quad$ SD Dec X SD Dec

13. Training of personnel/students on ICT. $\quad \begin{array}{lllllll}2.86 & 1.06 & \mathrm{~A} & 3.17 & 0.82 & \mathrm{~A}\end{array}$

14. Availability of ICT facilities for application $\quad \begin{array}{lllllll}3.04 & 1.00 & \mathrm{~A} & 3.18 & 0.94 & \mathrm{~A}\end{array}$

15. Regular maintenance of available facilities. $\quad \begin{array}{lllllll}2.90 & 1.11 & \text { A } & 3.18 & 0.94 & \text { A }\end{array}$

16 Organize seminar, workshop and talk on application

$\begin{array}{llllll}3.32 & 0.79 & \text { A } & 3.17 & 0.84 & \text { A }\end{array}$

17. Adequate funding of university

$\begin{array}{llllll}3.27 & 0.91 & \text { A } & 3.11 & 0.90 & \text { A }\end{array}$

18. Nigeria becoming producers of ICT

$\begin{array}{llllll}2.94 & 1.08 & \mathrm{~A} & 3.11 & 0.90 & \mathrm{~A}\end{array}$

19. Legislative support for use of ICT

$\begin{array}{llllll}2.15 & 1.08 & \mathrm{~A} & 1.86 & 0.98 & \mathrm{~A}\end{array}$

Table 2 indicates the opinion of personnel in federal state universities on procedures for the application of ICT in the management of student personnel services. The table reveals that items 13 to 18 have mean scores of 2.86, 3.04, 2.90, 3.32, 3.27 and 2.94 for personnel in federal universities. and 3.17, 3.29, 3.18, 3.17, 3.01, and 3.11for the states while item 19, has a low mean score of 2.15 for personnel in federal and 1.86 in state universities respectively. The respondents however disagree with legislative support in the use of ICT. This was because there is existing national policy on ICT that support the integration of ICT in student personnel services. 
Table 3: Mean Responses on Likely Problems that could hinder the Application of ICT

S/N Areas for Application

Federal University State University

$X \quad$ SD $\quad$ Dec $X \quad$ SD $\quad$ Dec

20. Insufficient ICT facilities for application. 2.91 $\quad 1.05 \quad$ A $\quad 3.14 \quad 0.90 \quad$ A

21. Lack of coherent national ICT policy. $\quad \begin{array}{lllllll} & 2.35 & 1.14 & \mathrm{D} & 1.85 & 0.95 & \mathrm{D}\end{array}$

22. Poor maintenance of ICT facilities. $\quad \begin{array}{llllll}3.08 & 1.99 & \text { A } & 3.02 & 1.04 & \text { A }\end{array}$

23. Resistant to change from obsolete to technology facilities.

$\begin{array}{llllll}2.54 & 1.16 & \text { A } & 3.29 & 0.90 & \mathrm{~A}\end{array}$

24. Lack of funds to produce ICT facilities

25. High cost of ICT resources

26. Intermitted disruption of electricity

27 Fear of using ICT facilities by students and personnel

$\begin{array}{llllll}3.03 & 0.96 & \mathrm{~A} & 3.25 & 0.01 & \mathrm{~A}\end{array}$

Lack of training in the use of ICT

Facilities

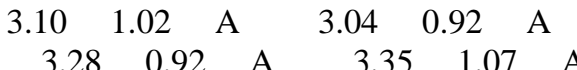

Table 3 reveals the views of the respondents on likely problems that might hinder the application of ICT in the management of student personnel services. The table indicates that all the items have mean ratings above the criterion mean score of 2-50 for both personnel in federal and state universities in North Central Zone.

Hypothesis one

There is no significant difference in the mean ratings of personnel in federal and personnel in state universities with regards to areas in which ICT can be applied in the management of student personnel services.

Table 4: $\quad$ Summary of t-ten Analysis on Areas in which ICT can be Applied in the Management of Student Personnel Services.

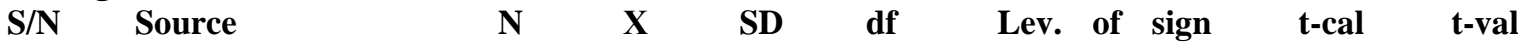

Decision

1. Federal Universities $281 \quad 3.15$

2. State Universities $\quad 167 \quad 3.16 \quad 0.96$

$\begin{array}{lllll}446 & 0.05 & 0.41 & 1.96 & \text { Not sig. }\end{array}$

Table 4 indicates that the calculated t-value is 0.41 at 446 degree of freedom and at 0.05 level of significance. Since the calculated value of 0.41 is less than the table value of 1.96 , the null hypothesis of the study is accepted as stipulated. Therefore, there is no significant difference in the mean ratings of personnel in federal and state universities on areas in which ICT can be applied in the management of student personnel services.

\section{Hypothesis Two}

There is no significant difference in the mean ratings of personnel in federal and personnel state universities with regards to likely problems associated with the application of ICT in management of student personnel services.

Table 5: $\quad$ Summary of t-test Analysis on Likely Problems might hinder the Application of ICT in the Management of Student Personnel Services

$\begin{array}{llccccccccc}\text { S/N } & \text { Source } & \mathbf{N} & \mathbf{X} & \text { SD } & \text { df } & \text { Lev. of sign } & \text { t-cal } & \text { t-val } & \text { Dec. } \\ 1 . & \text { Federal Universities } & 281 & 2.93 & 1.02 & & & & & & \\ & & & & & 446 & 0.05 & 0.54 & 1.96 & \text { Not sig. } \\ \text { 2. } & \text { State Universities } & 167 & 2.94 & 0.88 & & & & & \end{array}$

Table 5, reveals that the calculated t-value of 0.54 at 446 degree of freedom and 0.05 of significance is less than the table value of 1.96. The second null hypothesis of the study is accepted. Therefore, there is no significant difference in the mean ratings of personnel in federal and state universities on likely problems that might hinder the application of ICT in the management of student personnel services.

\section{Discussion}

From the results of the data analysis made, it is obvious that there are similarities between personnel in federal and state universities in their responses. The findings on areas in which ICT can be applied in the management of student personnel services revealed accessing of result on-line; filling of student personal data; communication among students, personnel and administration registration of courses and the use of ICT in records keeping. These results are not surprising because each of those areas requires the application of ICT to function fast and more effectively too. The findings are in agreement with Niyaz (2011) who opined that the application of ICT is necessary in areas of collection of students' data, recording of students results and for 
effective keeping of students records. Data of various types could be programmed into the computer and retrieve in later date when needed. Results from respondents agreed with the hypothesis made that there is no significant difference between the mean ratings of personnel in federal and personnel in state universities with regards to areas in which ICT can be applied in the management of student personnel services.

These responses and results of most of the analytical findings are supportive in accepting the null hypothesis as stated above that there is no significant difference in the mean ratings on areas in which ICT can be applied in the management of student personnel services in universities.

In the case of procedures for the application of ICT in the management of student personnel services, the respondents are in agreement that procedures to be adopted include, training of personnel/students in the use of ICT; availability of ICT facilities, regular maintenance of available ICT facilities and school administration to organize seminar; conference and talk on the use of ICT. Adeosun (2002) stated that through these processes, the problems of application are identified and how to solve them are discussed between the university administration and university personnel to improve the application of ICT in students personnel services.

Similarly, both personnel in federal and state universities agreed that likely problems that might hinder the application of ICT in student personnel services include intermitted disruption of electricity, lack of funds to procure ICT facilities and poor maintenance of available ICT facilities. This implies that university administration could not procure ICT equipment needed for the management of student personnel services. The results from the respondents agreed with the second hypothesis which stated that there is no significant difference between the mean ratings of personnel in federal and personnel in state universities on likely problems that might hinder the application of ICT in the management of student personnel services in universities in North central Nigeria.

\section{Conclusion}

Considering the findings of the study, it was concluded that there are areas in which ICT can be applied in the management of student personnel services. This is evident in the findings of this study which indicated a high level of application in the collection of student data, computation of students' results, record keeping and allocation of hostel accommodation. However, students and personnel require training in the use of ICT for effective student personnel services. The findings have led the researchers to conclude that provision of ICT facilities are significantly related to procedures for improving the application of ICT in the management of student personnel services. It was therefore, concluded that intermitted disruption of electricity and lack of adequate funds to procure ICT equipment are major problems inhibiting the application of ICT in the management of student personnel services in universities in North central Nigeria.

\section{Recommendation}

Based on the findings in this study, the following recommendations were made bearing in mind the importance of ICT in the management of student personnel services.

1. University administration in North central should make effort to partner with alumni and firms operating in the states where the universities are sited to establish a consultancy unit or endowment of chair to provide ICT facilities and to develop the state of ICT for effective management.

2. Adequate funds should be provided by government and the individuals that are concerned with university education for the purchase of ICT facilities. Students may also be made to pay ICT fees in order to generate income for the procurement of ICT facilities for onward student utilization of ICT in record keeping, communication, counseling services etc.

3. relevant skills for maintenance and acquisition of software skills especially, major decision like computation of student semester results, registration of students and other management functions should be developed through training by university administration for effective and efficient student personnel service delivery.

4. University administration should endeavour to make Internet facilities available in all offices. Enabling environment should be created in the classroom to encourage the use of ICT aided devices in provision of services to students within the class and outside the classroom.

\section{Summary}

This study investigated the application of ICT in the management of student personnel services in north central Nigeria. The findings of the study showed among several issues that ICT can be applied in the areas of accessing of result on line, filing of student personal data and communication. It was recommended that the state government should supply the necessary ICT equipment to all adult literacy centers in the state, among other recommendations. 


\section{References}

[1]. Adeosun, V.O (2002). Relative effects of three multi-medial packages on students achievement and retention in social studies. Doctoral research thesis carried out at the University of Ado Ekiti, Nigeria. Pp. 91-106

[2]. Adeyemi, T.O. (2007). Research methods and thesis writing in educational studies, New Haven Publishers, Lagos

[3]. Ahmad, Niyaz (2011), "Effective Educational Management: An Implementation of ICT in Administration of Higher Education Institutions", Articlesbase Ltd., Petach Tikva, 49517, Israel

[4]. Becta, B (2008). What is ICT? British educational communication and technology agency.http://school.Becta.org.uk, Accessed 9/9/2008

[5]. Harold Koontz \& Cyril O'Donnell (1974), Essentials of management, New York, McGraw-Hill [1974], ISBN: 0070353719

[6]. Lundy, James L (1957), Effective industrial management, Macmillan, New York, Bib ID 2271400

[7]. Ramoni Ayobami Alani, Phillips Olaide Okunola, Sikiru Omotayo Subair (2010), "Situation analysis of students' welfare services in universities in South-Western Nigeria: Implications for students' personnel management practice", US-China Education Review, ISSN 1548-6613, USA, October 2010, Volume 7, No.10 (Serial No.71)

[8]. Terry George R. (2012 ed), "Principles of management", 13th ed by Anand Chitipothu, Homewood, Illinois, United States 